\title{
Authenticity of gastronomic events as a function of branding a destination
}

\author{
Slobodan Čavić ${ }^{1 *}$, Marija Mandaric ${ }^{2}$ \\ ${ }^{1}$ Academy for Applied Studies Belgrade, The College of Hotel Management, Belgrade, \\ Serbia \\ ${ }^{2}$ University of Kragujevac, Faculty of Hotel Management and Tourism in Vrnjačka Banja, \\ Serbia
}

\begin{abstract}
The promotion of authentic food and beverages in Vojvodina is most commonly carried out in gastronomic events. Vojvodina is rich in gas tronomic products coming from the households of different nations that inhabit its territory. Gastronomic events with their authenticity can contribute to the creation of the destination brand. The aim of the present study is to explore the authenticity of gastronomic events, which could contribute to a better promotion of Vojvodina and the creation of a recognizable brand of this tourist destination. The research was conducted through the method of survey, using a questionnaire on a sample of 150 res pondents. Using statistical methods of binary logistic regression, Chi - square and Fisher's test, the analysis was performed and the results were presented. The findings of the research indicate that the authenticity of gastronomic events is recognized by the tourists; however, this should be better utilized in destination branding, as this feature could be the key in attracting tourists.
\end{abstract}

Keywords: gastronomic events, destination branding, Vojvodina JEL classification: M31, Z32, L66

\section{Autentičnost gastronomskih manifestacija u funkciji brendiranja destinacije}

Sažetak: Promocija autentične hrane i pića na teritoriii Voivodine naičešće se vrši putem gastronomskih manifestacija. Vojvodina je bogata gas tronoms kim proizvodima koji dolaze iz domaćinstava različitih naroda koji naseliavaju njenu teritoriju. Gastronomske manifes tacije sa svojomautentičnošću mogu doprineti kreiranju brenda destinacije. Cilj rada je da se istraži autentičnost gastronomskih manifestacija, koja može doprineti boljoj promovisanosti Vojvodine i stvaranju prepoznatliivog brenda ove turističke destinacije. Is traživanje je sprovedeno primenommetode is pitivanja, korišćenjem ankete, na uzorku od 150 is pitanika. Primenom statističkih metoda binomne logističke regresije, Hi-kvadrat i Fišerovog testa, izvršena je analiza i prezentovani su rezultati. Is traživanje pokazuje da je autentičnost gastronomskih manifestacija prepoznatljiva kod turista, ali da je treba bolje

*slobodan.cavic@vhs.edu.rs

This article is an open access article distributed under the terms and conditions of the Creative Commons Attribution (CC BY) license (http://creativecommons.org/licenses/by/4.0/). 
iskoristiti za brendiranje destinacije, jer upravo ovaj atribut može da bude ključan za privlačenje turista.

Ključne reči: gastronomske manifestacije, brendiranje destinacije, Vojvodina JEL klasifikacija: M31, Z32, L66

\section{Introduction}

Events can contribute to the recognizability of a city, region, as well as a country, and their authenticity is an important aspect of branding. Branding of a certain gastronomic event can affect the overall perception and creation of the image of the tourist destination its elf. The recognizability and authenticity of a certain event, in fact, brings potential touris ts to a certain destination. The aim of branding is to differentiate a certain product on the market from other products (Mandarić, 2016). Intense competition between tourist destinations is increasingly present, and therefore the need for destination branding is becoming more pronounced. The is sue of recognizability as well as authenticity is precisely the task of the brand. Tourist destination branding is a concept that started developing in the late XX century and integrates all the features of the destination into a single whole, which expresses a unique identity and differentiates the destin ation fromthe competition (Tsaur et al., 2016). Gas tronomic events have become increasingly important in recent years, as they attract an increasing number of tourists. Gastronomic events held in rural areas have a great promotional and entrepreneurial potential, as the gastronomic products from these events could be offered to local res taurants, as well as to retail chains, which would positively affect the revitalization of the rural area of a particular tourist destination (Stojanović et al., 2020). The events can be used to promote the destination as a gastronomic touris m destination. There are numerous gastronomic events in Vojvodina held every year at a certain time. Authentic food and drinks, which are characteristic of the venue of the gas tronomic event, are presented through the events. It can be said that "food also provides 'authentic' representation of the culture for the tourist" (Vuković \& Mosurović Ružičić, 2020, p. 79). Gastronomic products are a very important tool for introducing tourists to the culture, tradition and history of a particular place or region. The paper focuses on the gastronomic events that, with their authenticity, could influence the creation of recognizability, as well as a better promotion of Vojvodina as a tourist destination. Creating a brand and developing perceptions among tourists and locals can significantly contribute to the economic strengthening of villages, towns and the region.

\section{Gastronomic events and destination branding}

The number of gastronomic events in the world is constantly increasing, along with the growing interest in gastronomic tourism, which is a very interesting form of recreation and tourist attraction (Wargenau \& Che, 2006). "Events or organized events, as a reflection of modern touris m, with regard to culture (music festivals, concerts, exhibitions, contests etc.), sports (regattas, water-skiing, etc.), tradition (carnivals, gas tronomy, folklore, etc.), are gaining more importance in modern tourism" (Jovanović, 2015, p. 137). The combination of food, culture and touris $m$ has become an emerging tourism product called gastronomy, regarded as a vehicle for regional, local and sustainable development of a particular destination (Mohanty et al., 2020). Gastronomic events represent a unique connection between food, drinks, tourist events and travel. Gas tronomic events involve gathering a large number of people in one place, with the aim of tasting food and drinks, observing or participating in the preparation of food and beverage, as well as entertainment and leisure through the accompanying cultural and artistic program or competition. Since these events 
are mostly held in smaller towns and villages, there are conditions for the development of rural and gas tronomic tourism(Bjeljac, 2010). In recent years, there have been an increasing number of events aiming to present the gastronomy of a particular part of the country. This is precis ely where one can seek theopportunity for a larger number of visitors, both domestic and foreign. Through the affirmation of authentic food and beverages, any region can become a significant tourist destination, and one of the means to present and promote them can be through gastronomic events (Stojanović et al., 2018). According to Vićentijević (2015), events play a significant role in improving the quality of the tourist offer of Serbia, especially as one of the reasons for visiting certain destinations beyond the primary motive (s pa, mountain and other tourist products). The importance of gas tronomic events can be observed through the improvement of cultural, economic and overall social potential of a tourist destination. Some events are traditionally held every year and have become an integral part of the tourist offer. Some towns and cities are known for their gastronomic events (Milićević \& Đorđević, 2016). It is very important that the organization of events in a certain destination affect the growth of tourism in the same area. The promotion and affirmation of an event is at the same time the promotion of the destination where it is held. Holding recognizable events leads to a larger number of visitors, and the most important are those who would not visit the destination if it were not for that event (Mandaric \& Stamenković, 2017). In case the event is a positive experience for the visitors, their re-vis it is expected, and probably recommendations to relatives and friends. Poorly organized events can worsen the image and perception of the destination. It is impossible to observe events and their effects separately from tourism, or from the economy, as they are inextricably linked (Unković \& Zečević, 2011). A clearly defined gastronomic identity and heritage can be exploited in key differentiation processes, helping to convey a unique sense of a tourist destination (Fox, 2007).

A large number of tourist destinations on the market are reminiscent of each other - they have good conditions for stay and emphasize the uniqueness of their own culture and heritage. However, the perception of a particular destination has to be distinct (Mandaric, 2016). In the era of global economy and the growing need to achieve competitive advantage, "strong brands and the branding process itself are gaining importance, which is why the principles of brand management are applied even to geographical areas and destinations" (Jojić Novaković \& Mandarić, 2019, p. 47).

The goal of branding a tourist destination is to create such a perception in the minds of consumers that there is no other place as that one in the tourist market, that it is special and should be remembered as unique. However, it is important to take into account the fact that branding does not happen on the market, but exclusively in the minds and awareness of the consumers (Mandarić, 2016). A brand is the result of all the mental connections that the consumer creates with a given entity (Brzaković et al., 2019). The importance of the brand comes from the fact that it is a strategic asset for competitive advantage (Terzić \& Đalić, 2019). The need for destination branding nowadays is becoming more pronounced since numerous destinations may have high quality content and services but at the same time may not be recognizable on the market. In this respect, destinations may be similar and then the brand becomes an important factor as it gives added value and a promise to potential tourists that they will experience something special there, something worth a visit. Therefore it is important to create a perception in the minds of tourists about the uniqueness of the destination (Perić \& Mandarić, 2020). Branding of a destination, along with the strengthening of event touris $m$, can lead to significant economic results, the influx of new and retention of the existing touris ts, as well as the diversification of the overall tourist offer of a country. Vojvodina with its gastronomic events can certainly be a unique and authentic destination, which should be used in developing strategies and promotion. 


\section{Authenticity in the function of developing strong brands and gastronomic events}

Gas tronomic events can contribute to destination branding, which is significantly helped by the attribute of authenticity. "Authenticity shows whether a brand has a heritage and an established set of values, which is why it is able to meet the expectations of visitors" (Mandarić, 2016, p. 200). The authenticity of a brand is also related to the origin, as well as the uniqueness of a certain product. In the case of gastronomic products, this can be very significant for the tourists. When a certain product is typical of an area, it is promoted through gastronomic events that are recognizable. The authenticity of the gastronomic event is crucial in creating perception and loyalty among tourists. Gastronomic events "promote the culture of a destination and its culinary resources to enhance the tourist destination" (Carvache-Francoet al., 2020, p. 1328). The gastronomic events of Vojvodina offer a wide selection of food and drinks to tourists to satisfy their different tastes. Authentic food at events is a means of communication with vis itors who, in addition to participating in cultural activities, try gastronomic specialties characteris tic of a particular area and get to know the culture and traditions of the people wholive there. The gastronomy of Vojvodina has been formed under the influence of complexliving conditions, a large number of nations living on its territory, culturaland social events. Gastronomy can be considered as one of the most attractive tourist offers of Vojvodina, based on a large number of events offering culinary specialties (Stojanović, 2013). In the area of Vojvodina there is a mixture of cuisines with a large number of dishes. The Germans had a significant influence on gastronomy, as they brought theirown dishes and customs for preparing winter food stores, $g$ rowing fruit and vines, and making wine. Furthermore, the people of neighbouring countries, Romania and Hungary, as well as Slovakia and Russia, have left a large number of dishes that are still prepared in some parts of Vojvodina where these people live (Vojvodinian cuisine, 2021). A national gastronomy represents a historically originated cuisine that has developed in a certain territory, which is related to the culture, society, tradition, as well as the habits of the people who live there (Vukić, 2019). Attractive gastronomic offers of scattered isolated farms (granges), with different architectural and cultural traditions, are one of the main products that can be offered to guests. The gastronomic offer of Vojvodina is reflected in authentic food, desserts and wines, which are promoted and marketed through various events. The number of gastronomic events is at a high level, and includes numerous s pecifics of a certain place and people of that area. Moreover, through numerous mus eums of food and beverages, as well as granges, ethno houses, chardas and rural households, authentic Vojvodina specialties are offered and promoted. Gastronomy is significant because of its ethical and sustainable values that are based on local food, culture, traditions, lifestyles, practices that not only allu re the visitors but also at the same time promote the destination marketing (Mohanty et al., 2020). Gastronomic events increase the need for tourists to visit a certain destination; therefore, it is expected that these events, which are very important for the development of gastronomic tourism, will be more represented in the promotion of certain tourist places. Every region abounding in authentic gastronomic products should be represented and placed in the overall tourist offer of a particular country (Čavić \& Stojanović, 2018). In addition to the Dolovo StrudelFestival, in the area of the South Banat district there are well-known events dedicated to: preparation of goulash (Debeljača, Baranda, Omoljica), competitions in preparing soups and cauldron foods (Pančevo, Ivanovo, Kovin), bacon (Kačarevo), ham (Omoljica), desserts and cakes (Crepaja), ritual bread (Starčevo). Events dedicated to wine are present in the vine-growing area - Vršac, and events dedicated to brandy are held in Bela Crkva (Čavić \& Stojanović, 2018). All these events can be used as a unique and authentic gastronomic offer for tourists who visit or pas $\mathrm{s}$ through Banat. Traditional gas tronomic products, due to their character, quality and heritage, 
could "become a regionalbrand and als o promote the region as a unique destination of rural tourism” (Mandarić et al., 2017, p. 787).

Table 1: Number of gastronomic events in Vojvodina per months

\begin{tabular}{|lcc|}
\hline \multicolumn{1}{|c|}{ Variable } & Frequency & Percentage \\
\hline Month when the events are held & & 2.06 \\
\hline January & 4 & 10.31 \\
\hline February & 20 & 3.09 \\
\hline March & 6 & 2.59 \\
\hline April & 5 & 13.40 \\
\hline May & 26 & 10.82 \\
\hline June & 21 & 6.19 \\
\hline July & 12 & 16.49 \\
\hline August & 32 & 13.40 \\
\hline September & 26 & 11.86 \\
\hline October & 23 & 6.70 \\
\hline November & 13 & 3.09 \\
\hline December & 6 &
\end{tabular}

Source: Author's research

Table 1 shows the number of gas tronomic events held every month during a year. These events are officially regis tered and can be found on the website of the Tourist Organization of Vojvodina (Tourist Organization of Vojvodina, 2021). There are 194 of them in total, and they are placed under the category of gastronomic events and promotecertain food or drinks. Each of themis specific and unique, reflecting the people, tradition and culture of the place where they are held. We can conclude that the largest number of these events are held in August- 32 (16.49\%), whereas the smallest number in January - only $4(2.06 \%)$, as well as in April - 5 (2.59\%), March - 6 (3.09\%) and December - 6 (3.09\%). In other months, that number is increasing and it is much higher. In 2020 most of theseevents were not held due to the declared Covid 19 pandemic, or were just symbolically marked by the organizers so as not to break the tradition. However, the events did not have a large number of visitors as previous years, because of the res pect for epidemiological measures and the restrictions related to the gathering of a large number of people.

\section{Research methods and results}

The subject of the research are gastronomic events, which with their authenticity can influence the creation of recognizability, as well as better promotion of Vojvodina as a tourist destination. The research was conducted on the sample of 150 respondents, with a deliberate convenient s ample, through personal examination during the event Dolovo Strudel Festival in September 2019. All respondents were informed that the survey was anonymous and would be used for scientific purposes. After the review and processing, all 150 survey questionnaires were found valid. In the conducted field research, the examination method was used, and survey was used as a technique. The questionnaire consisted of 22 open-ended and closed-ended questions. The questions were divided into three segments. The first part referred to the socio-demographic characteristics of the respondents, whereas the second part was about the event itself (whether it is authentic, how they learned about it, what they find especially interesting etc.), and the questions in the third part were about the Dolovo strudel (whether they tried it, what type of strudel they prefer, whether it is authentic and promoted enough etc.). The respondents were the event visitors and members of several as sociations. To present the description of the research, descriptive statistical measures were used - 
frequencies and percentages. The questions from the questionnaire were categorical questions, so the choice of statistical tests is within the framework of non-parametric statistics. Binary logistic regression was used as the statistical method. Logistic regression was applied to examine the influence of several variables on one, and binary regression as the dependent variable is dichotomous. The Chi-square and Fisher's test were used to examine the differences. Statistical analyses were conducted within the statistical package SPSS 22.0 (Statistical Package for Social Sciences for Windows 22.0) (Leech et al., 2005; Pallant, 2011; Sheskin, 2004).

In order to gain a better understanding of the visitors to Dolovo Strudel Festival, Table 2 indicates the demographic characteristics of the respondents.

Table 2: Demographic characteristics of the respondents

\begin{tabular}{|lcc|}
\hline Variables & Frequency & Percentage \\
\hline Gender & & 19.3 \\
\hline Male & 29 & 80.07 \\
\hline Female & 121 & 18.0 \\
\hline Age & & 25.3 \\
\hline up to 35 & 27 & 56.7 \\
\hline from 36 to 50 & 38 & 62.7 \\
\hline over 50 & 85 & 31.3 \\
\hline Level of education & & 6.0 \\
\hline Elementary, high school & 94 & \\
\hline College, university & 47 & 9 \\
\hline Master's degree, PhD & 9 & \\
\hline
\end{tabular}

Source: Author's research

Table 2 shows that the number of female visitors to the event $(80.07 \%)$ is higher than the number of male visitors (19.3\%), which indicates that the population more interested in strudels and the event are women. Regarding the age of the respondents, most of them are over $50(56.7 \%)$, followed by those between 36 and 50 (25.3\%) and those younger than 35 $(18.0 \%)$. As far as the level of education is concerned, most respondents completed elementary and high school $(62.7 \%)$, college or university $(31.3 \%)$, whereas only $6.0 \%$ hold a Master's degree or PhD.

In order to examine the influence of the event programon the perception of the authenticity of the Dolovo Strudel Festival, the statis tical method of binary logistic regression was used. Criterion (dependent) variable is the authenticity of Dolovo StrudelFestival, operationalized through thequestion from the questionnaire: "Do you think that the event is authentic?" coded as dummy variable (categorical): 1 -yes and 0 - no. Predictor (independent) variables are the attractiveness of the overall program and the attractiveness of the competitive part of the event. The variable regarding the attractiveness of the competitive part of the event was operationalized through the question fromthe questionnaire: "Do you find the competitive part of this event interesting?", and the attractiveness of the overall program of the event through thequestion: "Do you find the program of the event interesting?". Both predictor variables are dichotomous coded as dummy variable: 1 - yes and $0-$ no. The model is statistically significant; $\chi^{2}(2)=21.68, p=0.00$; which indicates that the predictor variables significantly contribute to the interpretation of the criterion variable - the authenticity of the Dolovo Strudel Festival. Predictor variables interpret between 13.5 (Cox and Snell $R^{2}$ ) and 53.1 (Nagelkerke $\mathrm{R}^{2}$ ) the variances of the criterion variable. 
Table 3: Contribution of independent variables to the model of authenticity of the Dolovo Strudel Festival

\begin{tabular}{|c|c|c|c|c|c|}
\hline & & & & \multicolumn{2}{|c|}{$\begin{array}{c}95 \text { confidence } \\
\text { interval }\end{array}$} \\
\cline { 5 - 7 } & $\boldsymbol{\beta}$ & $\mathbf{p}$ & $\operatorname{Exp}(\mathbf{B})$ & $\begin{array}{c}\text { Lower } \\
\text { endpoint }\end{array}$ & $\begin{array}{c}\text { Upper } \\
\text { endpoint }\end{array}$ \\
\hline $\begin{array}{c}\text { Do you find the program of this } \\
\text { event interesting? (Yes) }\end{array}$ & 3.522 & 0.071 & 33.867 & 0.740 & 1550.785 \\
\hline $\begin{array}{c}\text { Do you find the competitive part of } \\
\text { this event interesting? (Yes) }\end{array}$ & 3.961 & 0.002 & 52.513 & 4.389 & 628.266 \\
\hline Constant & -2.376 & 0.219 & 0.093 & & \\
\hline
\end{tabular}

Source: Author's research

Table 3 shows that the attractiveness of the competitive part of the event significantly contributes to the interpretation of the authenticity of the Dolovo Strudel Festival, $\mathrm{p}<0.05$. Those who find the competitive part of the event interesting are more likely to perceive the event as authentic $(\mathrm{OR}=52.51 ; 95 \mathrm{CI}=4.39-628.27$; $\mathrm{p}=0.00)$ compared to those who do not find it interesting. The competitive part of the event is very unique every year, as the quality of the strudels taking part in the competition is evaluated. Based on quality parameters such as: appearance of strudel, ratio of dough and filling, whether it is coated with eggs and has a nice crust, quality of dough and filling, harmony of taste etc., the expert jury selects and declares the best strudels in several categories. This is very interesting for all the visitors, as well as for the members of numerous as sociations.

In order to tes the differences between those who find the Dolovo Strudel Fes tival authentic and those who do not find it authentic, the Fis her exact test was used (Table 4). The results of Fisher's test indicate that those who consider the Dolovo Strudel Festival authentic are significantly different from those who do not find it authentic in their ans wer to the question: "Do you find the program of this event interesting?"; $p=0.00$. Almost all the respondents (99.3\%) who consider the Dolovo Strudel Festival authentic find the program of the event interesting, whereas $40 \%$ of the respondents who do not consider this event authentic do not find the program interesting. When asked: "In your opinion, is this event sufficiently promoted?", $120(80 \%)$ of the res pondents replied YES, and only $30(20 \%)$ replied NO. This is an indicator of a good promotion of the event; however, it does n ot mean that it should not be raised to an even higher level, in order to attract a larger number of visitors. In reply to "How did you learn about this event?", 102(68\%) respondents said that they heard about it from their friends, followed by $28(18.7 \%)$ respondents who learned about it on TV, and only $20(13,3 \%)$ learned about it on the Internet. This is very significant for planning future advertising and promoting the Dolovo Strudel Festival.

The results of Fisher's test indicate that those who consider the Dolovo Strudel Festival authentic are significantly different from those who do not find it authentic in their answer to the question: "Do you find the competitive part of this event interesting?"; $p=0.00$. Those who find the event authentic at the same time like the competitive part of the event (95.2\%), and those who do not think the event is authentic do not like the competitive part either $(80 \%)$. When asked "What do you consider authentic in this event?", the respondents mostly replied "strudels" $104(69.3 \%)$, then "programof the event" 38 (25.3\%) and "competition" 8 $(5.3 \%)$. Authenticity is a very important part of the brand. According to the respondents, 
Čavić, S., Mandarić, M. - Authenticity of gastronomic events as a function of branding a destination-

Hotel and Tourism Management, 2021, Vol. 9, No. 1: 89-101.

strudels are something authentic and therefore they can be the main advantage in branding of this event.

Table 4: Differences in terms of the authenticity of the event Dolovo Strudel Festival

\begin{tabular}{|c|c|c|c|c|c|c|c|c|}
\hline & \multicolumn{4}{|c|}{$\begin{array}{l}\text { Do you find the event } \\
\text { authentic? }\end{array}$} & \multicolumn{2}{|c|}{$\mathrm{N}$} & \multirow[b]{3}{*}{$\mathrm{p}$} \\
\hline & & \multicolumn{2}{|c|}{ no } & \multicolumn{2}{|c|}{ yes } & & & \\
\hline & & $\mathbf{f}$ & $\%$ & $\mathbf{f}$ & $\%$ & $\mathbf{f}$ & $\%$ & \\
\hline \multirow[t]{2}{*}{ Gender } & male & 2 & 40.0 & 27 & 18.6 & 29 & 19.3 & \multirow{2}{*}{0.248} \\
\hline & female & 3 & 60.0 & 118 & 81.4 & 121 & 80.7 & \\
\hline \multirow{3}{*}{ Age } & up to 35 & 2 & 40.0 & 25 & 17.2 & 27 & 18.0 & \multirow{3}{*}{0.653} \\
\hline & from 36 to 50 & 1 & 20.0 & 37 & 25.5 & 38 & 25.3 & \\
\hline & over 50 & 2 & 40.0 & 83 & 57.2 & 85 & 56.7 & \\
\hline \multirow{3}{*}{$\begin{array}{l}\text { Level of } \\
\text { education }\end{array}$} & $\begin{array}{l}\text { Elementary, } \\
\text { high school }\end{array}$ & 4 & 80.0 & 90 & 62.1 & 94 & 62.7 & \multirow{3}{*}{0.651} \\
\hline & $\begin{array}{l}\text { College, } \\
\text { university }\end{array}$ & 0 & 0.0 & 47 & 32.4 & 47 & 31.3 & \\
\hline & $\begin{array}{l}\text { Master's degree, } \\
\text { PhD }\end{array}$ & 1 & 20.0 & 8 & 5.5 & 9 & 6.0 & \\
\hline \multirow{2}{*}{$\begin{array}{l}\text { Is this event } \\
\text { sufficiently } \\
\text { promoted, in y our } \\
\text { opinion? }\end{array}$} & no & 2 & 40.0 & 28 & 19.3 & 30 & 20.0 & \multirow[b]{2}{*}{0.261} \\
\hline & yes & 3 & 60.0 & 117 & 80.7 & 120 & 80.0 & \\
\hline \multirow{3}{*}{$\begin{array}{l}\text { How did you } \\
\text { learn about this } \\
\text { event? }\end{array}$} & TV & 1 & 20.0 & 27 & 18.6 & 28 & 18.7 & \multirow{3}{*}{0.655} \\
\hline & Internet & 1 & 20.0 & 19 & 13.1 & 20 & 13.3 & \\
\hline & $\begin{array}{l}\text { Friends' } \\
\text { recommendation }\end{array}$ & 3 & 60.0 & 99 & 68.3 & 102 & 68.0 & \\
\hline \multirow{3}{*}{$\begin{array}{l}\text { What do you } \\
\text { consider authentic } \\
\text { in this event? }\end{array}$} & strudels & 4 & 80.0 & 100 & 69.0 & 104 & 69.3 & \multirow{3}{*}{0.513} \\
\hline & $\begin{array}{l}\text { program of the } \\
\text { event }\end{array}$ & 1 & 20.0 & 37 & 25.5 & 38 & 25.3 & \\
\hline & competition & 0 & 0.0 & 8 & 5.5 & 8 & 5.3 & \\
\hline \multirow{2}{*}{$\begin{array}{l}\text { Have y ou tried } \\
\text { Dolovo strudel } \\
\text { before? }\end{array}$} & no & 1 & 20.0 & 28 & 19.3 & 29 & 19.3 & \multirow[b]{2}{*}{0.664} \\
\hline & yes & 4 & 80.0 & 117 & 80.7 & 121 & 80.7 & \\
\hline \multirow{5}{*}{$\begin{array}{l}\text { Which strudel do } \\
\text { you like tasting } \\
\text { most? }\end{array}$} & $\begin{array}{l}\text { Poppyseed } \\
\text { strudel }\end{array}$ & 3 & 60.0 & 87 & 60.0 & 90 & 60.0 & \multirow{5}{*}{0.677} \\
\hline & Walnut strudel & 1 & 20.0 & 37 & 25.5 & 38 & 25.3 & \\
\hline & Carob strudel & 0 & 0.0 & 10 & 6.9 & 10 & 6.7 & \\
\hline & $\begin{array}{l}\text { Fruit filling } \\
\text { strudel }\end{array}$ & 1 & 20.0 & 8 & 5.5 & 9 & 6.0 & \\
\hline & $\begin{array}{l}\text { Savory filling } \\
\text { strudel }\end{array}$ & 0 & 0.0 & 3 & 2.1 & 3 & 2.0 & \\
\hline \multirow{2}{*}{$\begin{array}{l}\text { Do y ou think that } \\
\text { the Dolovo } \\
\text { strudel is the best } \\
\text { cake of Banat? }\end{array}$} & no & 2 & 40.0 & 23 & 15.9 & 25 & 16.7 & \multirow[b]{2}{*}{0.194} \\
\hline & yes & 3 & 60.0 & 122 & 84.1 & 125 & 83.3 & \\
\hline \multirow{2}{*}{$\begin{array}{l}\text { Do y ou find the } \\
\text { program of this } \\
\text { event interesting? }\end{array}$} & no & 2 & 40.0 & 1 & 0.7 & 3 & 2.0 & \multirow[b]{2}{*}{0.003} \\
\hline & yes & 3 & 60.0 & 144 & 99.3 & 147 & 98.0 & \\
\hline \multirow{2}{*}{$\begin{array}{l}\text { Are you a member } \\
\text { of the Association } \\
\text { or a visitor? }\end{array}$} & association & 2 & 40.0 & 84 & 57.9 & 86 & 57.3 & \multirow[b]{2}{*}{0.651} \\
\hline & visitor & 3 & 60.0 & 61 & 42.1 & 64 & 42.7 & \\
\hline Do y ou find the & no & 4 & 80.0 & 7 & 4.8 & 11 & 7.3 & 0.000 \\
\hline
\end{tabular}




\begin{tabular}{|c|c|c|c|c|c|c|c|c|}
\hline $\begin{array}{l}\text { competitive part } \\
\text { of this event } \\
\text { interesting? }\end{array}$ & yes & 1 & 20.0 & 138 & 95.2 & 139 & 92.7 & \\
\hline \multirow{2}{*}{$\begin{array}{l}\text { Do y ou like the } \\
\text { idea of organizing } \\
\text { a collective } \\
\text { wedding for the } \\
\text { first time in this } \\
\text { event? }\end{array}$} & no & 0 & 0.0 & 8 & 5.5 & 8 & 5.3 & \multirow[b]{2}{*}{0.757} \\
\hline & yes & 5 & 100.0 & 137 & 94.5 & 142 & 94.7 & \\
\hline \multirow{3}{*}{$\begin{array}{l}\text { What are you } \\
\text { taking as a } \\
\text { souvenir from this } \\
\text { event? }\end{array}$} & strudels & 1 & 20.0 & 83 & 57.2 & 84 & 56.0 & \multirow{3}{*}{0.541} \\
\hline & handicrafts & 2 & 40.0 & 14 & 9.7 & 16 & 10.7 & \\
\hline & memories & 2 & 40.0 & 48 & 33.1 & 50 & 33.3 & \\
\hline \multirow{3}{*}{$\begin{array}{l}\text { The reason you } \\
\text { came to Strudel } \\
\text { Festival? }\end{array}$} & socializing & 2 & 40.0 & 86 & 59.3 & 88 & 58.7 & \multirow{3}{*}{0.649} \\
\hline & strudels & 0 & 0.0 & 41 & 28.3 & 41 & 27.3 & \\
\hline & curiosity & 3 & 60.0 & 18 & 12.4 & 21 & 14.0 & \\
\hline \multirow{2}{*}{$\begin{array}{l}\text { Do you think that } \\
\text { the Dolovo } \\
\text { strudel is a } \\
\text { recognizable } \\
\text { brand? }\end{array}$} & no & 2 & 40.0 & 8 & 5.5 & 10 & 6.7 & \multirow[b]{2}{*}{0.036} \\
\hline & yes & 3 & 60.0 & 137 & 94.5 & 140 & 93.3 & \\
\hline
\end{tabular}

Source: Author's research

The results of Fisher's test indicate that those who consider the Dolovo Strudel Festival authentic are significantly different fromthose who do not find it authentic in their answer to the question: "Do you find the competitive part of this event interesting?"; $p=0.00$. Those who find the event authentic at the same time like the competitive part of the event (95.2\%), and those who do not think the event is authentic do not like the competitive part either (80\%). When asked "What doyou consider authentic in this event?", the respondents mostly replied "strudels" $104(69.3 \%)$, then "programof the event" $38(25.3 \%)$ and "competition" 8 $(5.3 \%)$. Authenticity is a very important part of the brand. According to the respondents, strudels are something authentic and therefore they can be the main advantage in branding of this event.

The results of Fisher's test indicate that those who consider the Dolovo Strudel Festival authentic are significantly different from those who do not find it authentic in their answer to the question: "Do you think that the Dolovo s trudel is a recognizable brand?"; $p=0.04$. Those who consider this event authentic also think that the Dolovo strudel is a recognizable brand $(94.5 \%)$. The connection is very significant from the as pect of authenticity and uniqueness of this event. When asked "Have you tried Dolovo strudel before?" 121(80.7\%) res pondents said YES and they have already attended this event before, whereas $29(19.3 \%)$ respondents said NO. The aim of the question "Which strudel do you like tasting most?" is to show which type of strudel is most tasted and sought after among vis itors. Most respondents - $90(60 \%)-$ confirmed that is the poppyseed strudel, then walnut strudel - $38(25.3 \%)$ respondents, and the remaining three types of strudel are much less popular according to the respondents. Strudel is a cake that has traditionally been prepared and eaten in Banat for a long time. The question "Do you think that the Dolovo strudel is the best cake of Banat?" $125(83.3 \%)$ respondents answered YES, and only 25(16.7\%) res pondents said NO. When asked "Do you find the programof this event interesting?"147(98\%) respondents replied YES, and only 3 $(2.0 \%)$ said NO. This shows that the overall program of the Dolovo Strudel Festival is certainly well designed and interesting for visitors. The question "Are you a member of the 
Ass ociation or a visitor?", produced the following answers - 86 members of the As sociation $(57.3 \%)$, and 64 visitors $(42.7 \%)$, which is important in order to receive feedback from two different angles. When asked: "Do you find the competitive part of this event interesting?" $139(92.7 \%)$ respondents said YES, and only $11(7.3 \%)$ said NO, which indicates that the competitive part received a positive evaluation from the respondents. A collective wedding was organized in this event, so the respondents were asked "Do you like the idea of organizing a collective wedding for the first time in this event?"- $142(94.7 \%)$ respondents replied YES, and only $8(5.3 \%)$ said NO. The visitors were pleasantly surprised by the wedding, as this was an opportunity for a number of couples to get married as part of such a beautifulevent. When asked "What are you taking as a souvenir from this event?", most respondents said "strudels" $-84(56.0 \%)$, then "memories from this event" $-50(33.3 \%)$ and various types of handicraft $16(10.7 \%)$. An edible souvenir such as strudel can be something authentic and after the event the visitors have impressions to talk about. In reply to "The reas on you came to Strudel Festival?", most respondents said it was for socializing - 88 $(58.7 \%)$, taking into account the fact that such events are a great opportunity for the members of the as sociation and visitors to socialize and exchange experience, then "for strudels" - 41 (27.3\%) and "curiosity" as they heard about his event - 21 (14.0\%). When asked "Do you think that the Dolovo strudel is a recognizable brand?", 140 (93.3\%) res pondents said YES, and only $10(6.7 \%)$ respondents said NO. The results of this research indicate that this is an authentic gastronomic event which, with its program and strudels, has a significant role in the gastronomic offer of Vojvodina and Serbia. Gastronomic events with an authentic gas tronomic offer are increasingly attracting many domestic and foreign touris ts . However, they are stillnot sufficiently promoted, and they can contribute to the strengthening of the economy, both in the region and the entire country (Čavić \& Stojanović, 2018).

\section{Conclusions}

High attendance at a tourist destination and creating a brand at destination, through the development of event touris $m$, contribute to strengthening the competitive position of the destination, enable easier overcoming of geographical distance, attracting new and retaining exis ting tourists and visitors to the destination, while achie ving favourable economic effects (Mandarić \& Stamenković, 2017). The need for destination branding nowadays is becoming more pronounced as many destinations may have high quality content and services but are not necessarily recognizable on the market (Perić \& Mandarić, 2020). Vojvodina has a large number of gastronomic events held regularly, every year at the same time. Each of these events is characteris tic of the place where it is held, as it reflects and presents the people who live there, with theircustoms, culture and tradition. A number of as sociations and various societies have been formed, in order to present in an organized and adequate way an event that can become a kind of brand of a place, and thus an important segment of the tourist and gastronomic offer of Vojvodina and Serbia. The results of the research indicate that the gastronomic events held in Vojvodinaare authentic in terms of the uniqueness of the dishes, desserts and wines they promote and that in certain cases they represent the brand of a particular village, town or city.

The Dolovo StrudelFestival is an authentic event traditionally held in Dolovo near Pančevo. The distinctive feature of this event are Dolovo strudels, which are unique and attract an increasing number of tourists every year. The research indicates that the Dolovo Strudel Festival is recognized by the tourists who visit it, but it is still not promoted throughout Serbia although it would enable it to have a better placement in gas tronomic movements of touris ts. Many events are recognizable, unique and represent the brand of the place where they are held and of Vojvodina as a tourist destination. According to the Strategy for the development of tourism in Serbia for the period 2016-2025, events are positioned in the 
second place as a tourist product of special importance for the development of tourism. In the same document, gastronomic tourismis ranked among the modern trends in the motives of touris ts to visit a destination (Ministry of Trade, Tourism and Telecommunications, 2016).

One of the research limitations of the present study is the application of dichotomous (Yes/No) questions, preventing the respondents fromexpressing their attitudes more freely. Another limitation is the fact that the research does not apply to larger-scale events. Furthermore, new gastronomic events appear every year, with a more complexcontent, which might affect the authenticity of this particular event.

It is recommended that the promotion of the Dolovačka strudelevent, which was the subject of research in the paper, but also other gastronomic events that have great tourist potential, should be improved. Creating the perception and a positive image of a destination among potential tourists is important and it is something that all the capacities of the destination should be used to achieve. Marketing communication is very important in touris mand provision of information and the exchange of ideas and experiences (Marić et al., 2020) can help gas tronomic events to achieve better higher attendance. Some of the recommendations are to improve the information on the websites of tourist organizations, make gastronomic films about the events, improve thecontents and appearance of the brochures and leaflets, more frequent visits of the members of the Association in TV shows, form gas tronomic routes through the places where food and beverages are promoted, as well as all other activities thatcould improve the promotion and create a recognizable image and brand of Vojvodina as a tourist destination. The authenticity and uniqueness of gastronomic events can certainly be and should be a good basis for the promotion of gastronomy, for destination branding and for attracting both domestic and foreign tourists .

\section{Conflict of interest}

The authors declare no conflict of interest.

\section{References}

1. Bjeljac, Ž. (2010). Turističkemanifestacije u Srbiji [Touristevents in Serbia]. Belgrade: Serbian Academy of Sciences and Arts.

2. Brzaković, A., Brzaković, T., \& Brzaković, P. (2019). Creating brand market value. The Annals of the Faculty of Economics in Subotica, 55(42), 17-33. https://doi.org/10.5937/AnEkSub 1942017B

3. Carvache-Franco, M., Carvache-Franco, O., Carvache-Franco, W., \& Villagómez-Buele, C. (2020). Relationship between sociodemographic aspects, satisfaction and loyalty in gastronomic festivals. GeoJournal of Tourism and Geosites, 32(4), 1324-1329. https://doi.org/10.30892/gtg.32420-576

4. Čavić, S., \& Stojanović, D. (2018). Gastronomske manifestacije kao vid očuvanja autentičnih jela, poslastica i vina u Vojvodini [Gastronomic events as a form of preserving authentic dishes, sweets and wines in Vojvodina]. Znanstveno stručni skup s međunarodnim sudjelovanjem "130 godina organiziranoga vinogradarstva i vinarstvau Bosni i Hercegovini” [Scientific and Expert Meeting with International Participation "130 Years of Organized Viticulture and Winemaking in Bosnia and Herzegovina"]. Federal Agro-Mediterranean Institute Mostar, Faculty of Agriculture and Food technology, University of Mostar.

5. Fox, R. (2007). Reinventing the gastronomic identity of Croatian tourist destinations . Hospitality Management, 26, 546-59. https://doi.org/10.1016/j.ijhm.2006.03.001 
6. Jojić Novaković, Đ., \& Mandarić, M. (2019). Do events contributeto the brand of Novi Sad? A millennials' perspective. Menadžment u hotelijerstvu i turizmu - Hotel and Tourism Management, 7(1), 47-59. https://doi.org/10.5937/menhottur1901047J

7. Jovanović, V. (2015). Tematski turizam [Thematic tourism]. Belgrade: Singidunum University.

8. Leech, N., Barrett, K., \& Morgan, G. (2005). SPSS for intermediate statistics: Use and interpretation (2nd ed.). New Jersey: Lawrence Erlbaum Associates, Publishers.

9. Mandarić, M. (2016). Strategijskibrendmenadžment [Strategic Brand Management]. Vrnjačka Banja: Univers ity of Kragujevac, Faculty of Hotel Management and Tourism in Vrnjačka Banja.

10. Mandarić, M., Milićević, S., \& Sekulić, D. (2017). Traditionalvalues in the function of promotion of Šumadija and Pomoravlje as rural tourism destinations. Economics of Agriculture, 64(2), 787-803. https ://doi.org/10.1016/j.ijhm.2006.03.001

11. Mandarić, M., \& Stamenković, I. (2017). Is traživanje značaja manifestacija za razvoj i brendiranje grada Niša kao turističke destinacije [The research of the importance of events for the development and branding of the city of Niš as a tourism destination]. Menadžment u hotelijerstvu i turizmu - Hotel and Tourism Management, 5(1) 64-74.

12. Marić, D., Leković, K., \& Tomić, S. (2020). E-WOM through the prism of sociodemigraphic analysis of users of tourist services. Ekonomika, 66(4), 1-12. https://doi.org/10.5937/ekonomika2004001M

13. Milićević, S., \& Đorđević, N. (2016). Glavni gradovikao turističke destinacije [Capital cities as tourist destinations]. Menadžment u hotelijerstvu i turizmu-HotelandTourism Management, 4(1), 21-30.

14. Ministarstvo trgovine, turizma i telekomunikacija [Ministry of Trade, Tourism and Telecommunications] (2016). Strategija razvoja turizma Republike Srbije za period 2016-2025. [Tourism Development Strategy of the Republic of Serbia for the period 2016-2025]. Retrieved May 1, 2021 from http://mtt.gov.rs/download/3/strategija.pdf

15. Mohanty, P. P., Himans hu, B. R., \& Sapan, K. S. (2020). Food, culture and tourism: A gastronomy trilogy enhancing destination marketing, case study of Odisha, India. International Journal of Tourism \& Hospitality in Asia Pasific, 3(1), 15-30. https ://doi.org/10.32535/ijthap.v3i1.721

16. Pallant, J. (2011). SPSS survival manual (4th ed.). Australia: Allen \& Unwin.

17. Perić, G., \& Mandarić, M. (2020). Challenges in tourist destination branding in Serbia: The case of Prolom Banja. Ekonomika Preduzeća, 68(5-6), 442-456. https://doi.org/10.5937/EKOPRE2006442P

18. Sheskin, D. (2004). Handbook of parametric and nonparametric statistical procedures (3rd ed.). United States of America: Library of Congres.

19. Stojanović, D. (2013). Gastronomija kao faktor razvoja ruralnog turizma u Srbiji [Gastronomy as a factor of the development of rural tourism in Serbia] (Unpublished master's thesis ). Singidunum University, Department for Postgraduate Studies and International Cooperation, Belgrade.

20. Stojanović, D., Čavić, S., \& Stojanović, Đ. (2018). Importance of gastronomic manifestations of Eastern Serbia for tourism development. The 2nd International Conference on Management, Engineering and Environment ICMNEE 2018, Belgrade.

21. Stojanović, D., Vukić, M., Vukić, K., \& Jovanović, V. (2020). Satisfaction of visitors with food offer at gastronomic festivals in rural areas. Economics of Agriculture, 67(2), 523-536. https://doi.org/10.5937/ekoPolj2002523S

22. Terzić, S., \& Đalić, I. (2019). Analys is of brand valuation based on a combination of valuation models. The Annals of the Faculty of Economics in Subotica, 55(42), 33-48. https://doi.org/10.5937/AnEkSub 1942033T

23. Tourist Organization of Vojvodina. (2021). Retrieved May 5, 2021 from https://vojvodina.travel/ 
24. Tsaur, S. H., Yen, C. H., \& Yan, Y. T. (2016). Destination brand identity: Scale development and validation. Asia Pacific Journal of Tourism Research, 21 (12), 1310 1323. https://doi.org/10.1016/j.ijhm.2006.03.001

25. Unković, S., \& Zečević, B. (2011). Ekonomika turizma [Economics of tourism]. Belgrade: Faculty of Economics.

26. Vićentijević, D. (2015). Stanje i perspektive razvoja turističkog proizvoda: Događaji/ manifestacije u Srbiji [Status and prospects of tourism product development: Events/ festivals in Serbia]. Menadžment u hotelijerstvu i turizmu - Hotel and Tourism Management, 3(1), 11-19.

27. Vojvođanska kuhinja [Vojvodinian cuisine]. (2021). Retrieved May 6, 2021 from http://vojvodinacafe.rs/forum/kulinarstvo-i-ishrana/vojvodjanska-kuhinja-9975/

28. Vukić, M.(2019). Nacionalne gastronomije [National gastronomies]. Belgrade: The College of Hotel Management.

29. Vuković, P., \& Mosurović Ružičić, M. (2020). Potentials for development food tourism in AP Vojvodina in the Republic of Serbia. Ekonomika, 66(1), 77-92. https ://doi.org/10.5937/ekonomika2001077V

30. Wargenau, A., \& Che, D. (2006). Wine tourism development and marketing strategies in Southwest Michigan. International Journal of Wine Marketing, 18(1), 45-60. https://doi.org/10.1108/09547540610657678 